\title{
An interesting science experiment: hazards of magnets
}

\author{
Ishaan Maitra, ${ }^{1}$ Euan McLaughlin, ${ }^{2}$ Vinutha D Shetty ${ }^{2}$
}

${ }^{1}$ North West Deanery,

Preston, UK

${ }^{2}$ Upper GI Surgery, Preston, UK

Correspondence to

Dr Ishaan Maitra,

ishaan.maitra@googlemail.com

Accepted 13 March 2014

\section{DESCRIPTION}

Abdominal pain is a common problem in children. Although most children with acute abdominal pain have self-limiting conditions, the pain may be an indication of a surgical or medical emergency. ${ }^{1}$ Diagnoses of acute abdominal pain in children include gastroenteritis, appendicitis, mesenteric adenitis, constipation and very rarely intestinal obstruction. ${ }^{2}$ The most difficult challenge is making a timely diagnosis so that treatment can be initiated and morbidity prevented. ${ }^{3}$

A 12-year-old healthy boy was admitted with a 1-day history of sharp colicky central abdominal pain radiating to the right iliac fossa with associated

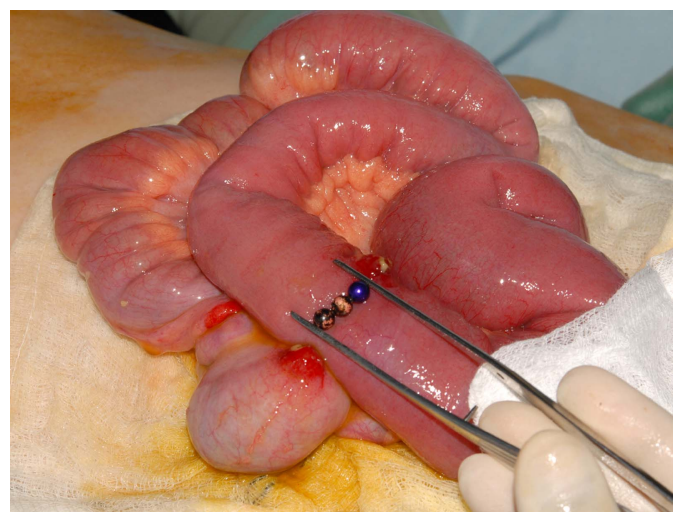

Figure 1 Magnetic beads causing pressure necrosis resulting in localised perforation sites at the ileum and caecum. vomiting. His observations were stable and his inflammatory markers were only slightly elevated. An ultrasound scan demonstrated small bowel obstruction with no convincing evidence of appendicitis.

A laparotomy was performed which revealed highly magnetic beads $4 \mathrm{~mm}$ in diameter which had caused an ileocaecal fistula (figure 1). The presumed mechanism was a focal pressure necrosis caused by the magnetic attraction of beads in the separate lumens of the caecum and ileum (figure 2). This fistula was sealed with appendices epiploicae from the caecum resulting in small bowel obstruction. The fistula was separated, closed primarily and a thorough washout was performed. Intraoperative imaging was used to ensure all magnets were removed. He was well enough for discharge 6 days later without any postoperative complications.

On further questioning he had accidentally swallowed one then two magnetic beads on consecutive days while at school 2 weeks previously. He was

\section{Learning points}

If the diagnosis is not clear after the initial evaluation, repeated physical examination by a senior physician is often useful.

- As a minimum, systematic investigations such as blood tests and plain radiographs should be performed on all children with abdominal pain.

Figure 2 Line schematic diagram representing presumed mechanism of fistula formation. 
using them as tongue piercings while in a physics class being taught the importance of magnetism.

Competing interests None.

Patient consent Obtained.

Provenance and peer review Not commissioned; externally peer reviewed.

\section{REFERENCES}

1 Leung AKC, Sigalet DL. Acute abdominal pain in children. Am Fam Physician 2003;67:2321-7.

2 Mason JD. The evaluation of acute abdominal pain in children. Emerg Med Clin North Am 1996;14:629-43.

3 Buchert GS. Abdominal pain in children: an emergency practitioner's guide. Emerg Med Clin North Am 1989;7:497-517.

Copyright 2014 BMJ Publishing Group. All rights reserved. For permission to reuse any of this content visit

http://group.bmj.com/group/rights-licensing/permissions.

BMJ Case Report Fellows may re-use this article for personal use and teaching without any further permission.

Become a Fellow of BMJ Case Reports today and you can:

- Submit as many cases as you like

- Enjoy fast sympathetic peer review and rapid publication of accepted articles

- Access all the published articles

- Re-use any of the published material for personal use and teaching without further permission

For information on Institutional Fellowships contact consortiasales@bmjgroup.com

Visit casereports.bmj.com for more articles like this and to become a Fellow 